\title{
UJI EFEKTIVITAS MANFAAT AIR LINDI PRODUKSI TEMPAT PEMBUANGAN AKHIR (TPA) TELAGA PUNGGUR SEBAGAI PUPUK ORGANIK CAIR TERHADAP PERTUMBUHAN MORFOMETRIK TANAMAN KANGKUNG DARAT (Ipomoea reptans, Poir)
}

\section{THE ADVENTAGE EFFECTIVENESS TEST OF THE LEACHATE FROM GARBAGE DUMP (GD) OF TELAGA PUNGGUR AS ORGANIC LIQUID FERTILIZER PLANT TOWARD WATER SPINACH (Ipomoea reptans, Poir) MORPHOMETRIC GROWTH}

\author{
Rika Meli Herlina ${ }^{1}$, Lani Puspita ${ }^{2}$, Fauziah Syamsi ${ }^{3}$ \\ ${ }^{1,2,3}$ Program Studi Pendidikan Biologi, FKIP, Universitas Riau Kepulauan, Batam
}

*Koresponden: lanipuspita@gmail.com

\begin{abstract}
Abstrak
Penelitian ini bertujuan untuk mengetahui penggunakan senyawa organik cair "Lindi” yang dihasilkan dari limbah sampah TPA Telaga Punggur Batam. Jenis sayuran yang digunakan adalah tanaman kangkung darat (Ipomoea reptans, Poir) dengan menggunakan indikator pengamatan pertumbuhan morfometrik sebagai dasar perbandingan, yakni dengan membandingkan efek antara cairan organik lindi dengan cairan pupuk umum yang tersedia di pasar. Hasil analisis pengujian berdasarkan nilai laju pertumbuhan panjang tangkai daun dengan menggunakan uji $\mathrm{F}(\alpha=5 \%)$ didapat bahwa $\mathrm{F}_{\text {hitung }}$ adalah 9.39 dan $F_{\text {tabel }} 3.88$ atau nilai $F_{\text {hitung }}>F_{\text {tabel}}$, berdasarkan hasil ini hipotesa alternatif $\left(\mathrm{H}_{\mathrm{i}}\right)$ diterima dan menolak $\mathrm{H}_{0}$, berarti bahwa senyawa organik cair lindi telah memberikan hasil signifikan dibandingkan pupuk umum. Sedangkan analisis hasil tes berdasarkan pada jumlah daun didapat bahwa $F_{\text {hitung }}$ adalah 32.06 dan $F_{\text {tabel }} 3.88$ atau nilai $F_{\text {hitung }}>F_{\text {tabel }}$ atau hipotesa menolak $\mathrm{H}_{0}$ menerima hipotesa alternatif $\left(\mathrm{H}_{\mathrm{i}}\right)$ serta menyatakan senyawa organik cair lindi telah memberikan hasil signifikan untuk dapat menambah jumlah daun dibandingkan pupuk umum.
\end{abstract}

Kata Kunci: Cairan senyawa organik Lindi, TPA, Pertumbuhan morphometrik, Tanaman kangkung darat (Ipomoea reptans. Poir)

\begin{abstract}
This study aims to determine the use of liquid organic "Leachate" produced by the garbage dump of Telaga Punggur, Batam. The kind of vegetable used was water spinach (Ipomoea reptans, Poir) using morphometric growth observation indicators as a basic of comparison, that is by comparing the effects of organic liquid leachate with available common liquid fertilizer at market. The results of the analysis of the test was based on the length of the growth rate of petiole using the $F_{\text {test }}(\alpha=5 \%)$, obtained

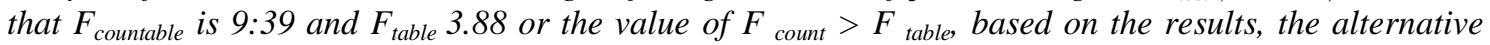
hypothesis $\left(H_{i}\right)$ is received and $H_{0}$ rejected. It means that the leachate liquid organic has provided significant $(S)$ results than common fertilizer. Meanwhile the analysis of test results based on the number of leaves obtained that $F_{\text {countable }}$ is 32.06 and $F_{\text {table }} 3.88$ or the value of $F_{\text {count }}>F_{\text {table }}$ or hypothesis rejected $H_{0}$ accepted the alternative hypothesis $\left(H_{i}\right)$ and the states that leachate organic liquid has provided significant results to increase the number of leaves compared to common fertilizers.
\end{abstract}

Keywords: Leachate Liquid Organic, garbage dump, Morfometric Growth, Water Spinach (Ipomoea reptans Poir). 


\section{PENDAHULUAN}

Tanaman kangkung darat dapat tumbuh dengan baik di sepanjang tahun, dapat tumbuh pada daerah yang beriklim panas ataupun beriklim dingin. Kangkung darat dapat tumbuh dengan baik, pada tanah yang subur, gembur, banyak mengandung bahan organik dan tidak di pengaruhi oleh keasaman tanah, dan jika tanah tergenang maka akar akan mudah membusuk (Aditia, 2009 dalam Aditama, 2011).

Laju pertumbuhan penduduk Indonesia khususnya kota Batam yang semakin hari makin meningkat menyebabkan meningkatya kebutuhan pangan termasuk sayuran. Oleh karena itulah dibutuhkan upaya peningkatan pangan dengan laju yang tinggi dan berkelanjutan sehingga dapat meningkatkan volume pemasaran sayur. Untuk memenuhi kebutuhan sayur, salah satu upaya yang dapat dilakukan adalah dengan pemberian pupuk.

Dalam penelitian ini penulis menggunakan pupuk organik cair berbahan dasar air lindi yang diambil dari tempat pembuangan akhir Telaga Punggur kota Batam. Untuk mengolah air lindi menjadi pupuk organik cair, agar dapat kembali digunakan sebagai sumber unsur hara yang baik bagi tanaman maka dilakukan penyaringan dan pencampuran air lindi dengan bakteri untuk mempercepat proses penguraian dan mempercepat pembuatan pupuk organik cair (Dinas Kebersihan dan Pertamanan kota Batam, 2013). Adapun tujuan penelitian ini untuk membuktikan apakah terdapat efektivitas pupuk organik cair lindi terhadap pertumbuhan tanaman tanaman Kangkung Darat.

\section{METODOLOGI}

Percobaan ini menggunakan pendekatan Rancangan Acak Lengkap (RAL), terdiri dari 2 perlakuan dengan 5 kali ulangan pada 2 jenis pupuk cair yang yang berbeda (pupuk organik cair lindi dan pupuk organik cair yang telah ada di pasaran sebagai pembanding), dan satu perlakuan kontrol dengan 5 kali ulangan. Sehingga total seluruh pot tanaman sebagai bahan penelitian adalah 15 pot. Persyaratan percobaan adalah adanya asumsi yang homogen yakni lingkungan percobaan homogen menggunakan pot ukuran yang sama, tanah yang sama dan dosis pupuk yang telah diencerkan juga sama serta bibit kangkung yang berasal dari satu keturunan.

Pemberian pupuk dilakukan dua kali selama penelitian, pertama diberikan pada 
saat sebelum bibit kangkung ditanam, dan yang kedua diberikan pada saat tanaman kangkung berumur 2 minggu. Penggunaan dosis pupuk untuk organik yang sudah ada di pasaran menggunakan dosis $5 \mathrm{ml} / 1$ liter air, berdasarkan kadar $\mathrm{N}$ yang terkandung didalam pupuk maka untuk menyamakan dosis digunakan dosis antara pupuk lindi dan pupuk organik yang telah ada dipasaran maka dosisnya adalah $1: 2$ atau $10 \mathrm{ml} / 1$ liter air untuk pupuk lindi. Pengamatan pertumbuhan dilakukan dengan mengamati pertumbuhan generativ secara berkala dengan mencatat perkembangan setiap 7 hari yang di mulai dari umur 7 hari hingga umur 21 hari, adapun pertumbuhan morfometik tanaman yang diamati yaitu: Tinggi Batang (cm) dan Jumlah Daun perhelai.

Analisis data hasil percobaan Y dinyatakan dalam model matematik bahwa data Y merupakan nilai rata-rata $(\mu)$ yang berfariasi sebagai adanya perlakuan $(\tau)$ dan galat ( $\varepsilon$ ) akibat adanya ulangan (Hanafiah, 2005). Formula analisis sebagai berikut;

$$
\mathrm{Y}=\mu+\tau+\varepsilon
$$

\section{PEMBAHASAN}

\section{Pertambahan Tinggi tanaman}

Hasil uji efektivitas pupuk organik cair lindi pada pertambahan tinggi batang tanaman kangkung darat ditampilkan dalam bentuk grafik batang pada Gambar 1.

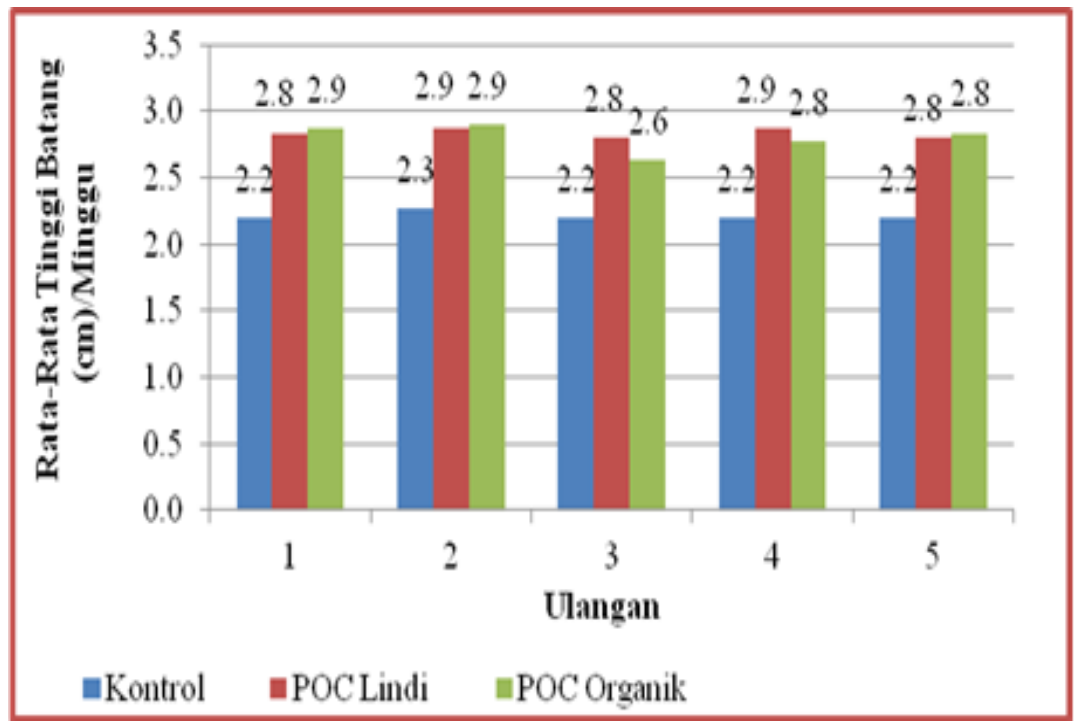

Gambar 1. Rata-Rata pertumbuhan Tinggi Batang Tanaman Kangkung. 
Dari Gambar 1. dapat dilihat perbedaan perlakuan kontrol dengan perlakuan penggunaan pupuk organik cair lindi dan pupuk organik cair yang sudah ada di pasaran terhadap rata-rata tinggi batang tanaman kangkung perminggu, menunjukan bahwa ratarata tinggi batang tanaman kangkung dengan perlakuan pupuk organik cair lindi dan pupuk organik cair yang sudah ada di pasaran lebih tinggi dari pada batang tanaman kangkung darat dengan perlakuan kontrol atau tanpa pemberian pupuk. Sementara itu tinggi batang tanaman kangkung dengan POC lindi dan POC organik menunjukan tinggi yang sama.

Dengan demikian dapat disimpulkan bahwa pupuk organik cair lindi memiliki efektivitas yang sama dengan pupuk organik yang sudah ada di pasaran terhadap tinggi batang tanaman kangkung darat. Hasil analisis ragam efektivitas pupuk organik cair lindi terhadap laju pertumbuhan tanaman kangkung darat ditampilkan dalam Tabel 1.

Tabel 1. Hasil Analisis Ragam Tinggi Batang Tanaman Kangkung Darat.

\begin{tabular}{|c|c|c|c|c|c|c|}
\hline \multirow{2}{*}{$\begin{array}{c}\text { Sumber } \\
\text { Keragaman } \\
\text { (SK) }\end{array}$} & \multirow{2}{*}{$\begin{array}{c}\text { Drajat } \\
\text { Bebas } \\
(\mathrm{db})\end{array}$} & \multirow{2}{*}{$\begin{array}{c}\text { Jumlah } \\
\text { Kuadrat } \\
\text { (jk) }\end{array}$} & \multirow{2}{*}{$\begin{array}{l}\text { Kuadrat } \\
\text { Tengah } \\
\text { (KT) }\end{array}$} & \multirow[t]{2}{*}{ F Hitung } & \multicolumn{2}{|c|}{ F. Tabel } \\
\hline & & & & & 0.05 & 0.01 \\
\hline Perlakuan & 2 & 0.134 & 0.067 & & & \\
\hline Acak & 42 & 0.302 & 0.007 & 9.39 & 3.23 & 5.18 \\
\hline Total & 44 & 0.438 & & & & \\
\hline
\end{tabular}

Berdasarkan hasil analisis ragam tinggi batang tanaman kangkung, maka didapat nilai $F_{\text {hitung }}=9.389$ sedangkan $F_{\text {tabel }}(3.23)$ pada taraf uji 5\% dan (5.18) pada taraf uji $1 \%$. Karena $\mathrm{F}_{\text {hitung }}$ lebih besar dari pada $\mathrm{F}_{\text {tabel }}$ pada taraf uji $(5 \%)$ dan $(1 \%)$ maka $\mathrm{H}_{0}$ di tolak dan $\mathrm{H}_{1}$ diterima, sehingga disimpulkan bahwa pemberian pupuk organik cair berpengaruh sangat nyata terhadap tinggi batang tanaman kangkung darat (Ipomoea reptans Poir).

Hasil dari perhitungan Koefisien Keragaman (KK) untuk rata-rata tinggi batang per-minggu uji efektifitas pupuk organik cair lindi terhadap laju pertumbuhan tanaman kangkung darat adalah; 4,56 \%. Nilai KK ini untuk kondisi homogen tergolong kecil $(4,56<5 \%)$ berarti tingkat erorr (galat) pada penelitian ini Sangat kecil, sehingga penelitian dilanjutkan dengan uji BNJ (uji beda nyata jujur), untuk menilai apakah dua rata-rata yang dibandingkan berbeda nyata atau tidak (Hanafiah, 2005). Hasil uji BNJ ditampilkan pada Tabel 2. 
Tabel 2. Hasil Uji BNJ Tinggi Batang Tanaman Kangkung Darat.

\begin{tabular}{ccccc}
\hline Perlakuan & Kontrol & POC Lindi & POC Organik & \multirow{2}{*}{ Nilai BNJ } \\
\cline { 2 - 4 } y & 0.33 & 0.44 & 0.44 & \\
BNJ 5\% & $\mathrm{a}$ & $\mathrm{b}$ & $\mathrm{b}$ & 0,062 \\
BNJ 1\% & $\mathrm{a}$ & $\mathrm{b}$ & $\mathrm{b}$ & 0,083 \\
\hline
\end{tabular}

Dari hasil analisis pengujian BNJ pada Tabel 2. perlakuan kontrol tidak berpengaruh nyata terhadap laju pertambahan tinggi batang tanaman kangkung sedangkan perlakuan POC Lindi dan POC organik sangat nyata pengaruhnya. Sehingga memberikan pertumbuhan tanaman dengan respon yang berbeda pada kemampuan pertumbuhnya. Interaksi yang terjadi antara kedua perlakuan (di luar perlakuan kontrol) pada pengamatan pertambahan tinggi batang tanaman menunjukan perlakuan menggunakan pupuk organik cair yang sudah ada dipasaran dan pemberian pupuk organik cair lindi memberikan respon yang sama baiknya terhadap pertumbuhan batang pada tanaman kangkung darat. Pada uji BNJ tidak terdapat perbedaan yang nyata antara kedua perlakuan dan menunjukan bahwa pupuk organik cair lindi dan pupuk cair organik cair yang sudah ada dipasaran memberikan hasil yang sama baiknya. Dari hasil uji F dan BNJ dapat disimpulkan bahwa pemberian pupuk organik cair berbahan dasar air lindi terbukti dapat meningkatkan laju pertambahan tinggi batang tanaman kangkung darat (Ipomoea reptans Poir) secara sangat nyata.

\section{Pertambahan Jumlah Daun}

Hasil uji efektifitas Pupuk organik cair lindi terhadap pertambahan jumlah daun pada tanaman kangkung darat di tampilkan dalam grafik pada Gambar 2, dapat dilihat perbedaan perlakuan kontrol dengan perlakuan penggunaan pupuk organik cair lindi dan pupuk organik cair yang sudah ada di pasaran terhadap jumlah daun tanaman kangkung, menunjukan bahwa rata-rata jumlah daun dengan perlakuan pupuk organik cair lindi dan pupuk organik cair yang sudah ada di pasaran lebih tinggi dari pada pertambahan jumlah daun tanaman kangkung darat tanpa perlakuan atau tanpa pemberian pupuk. 


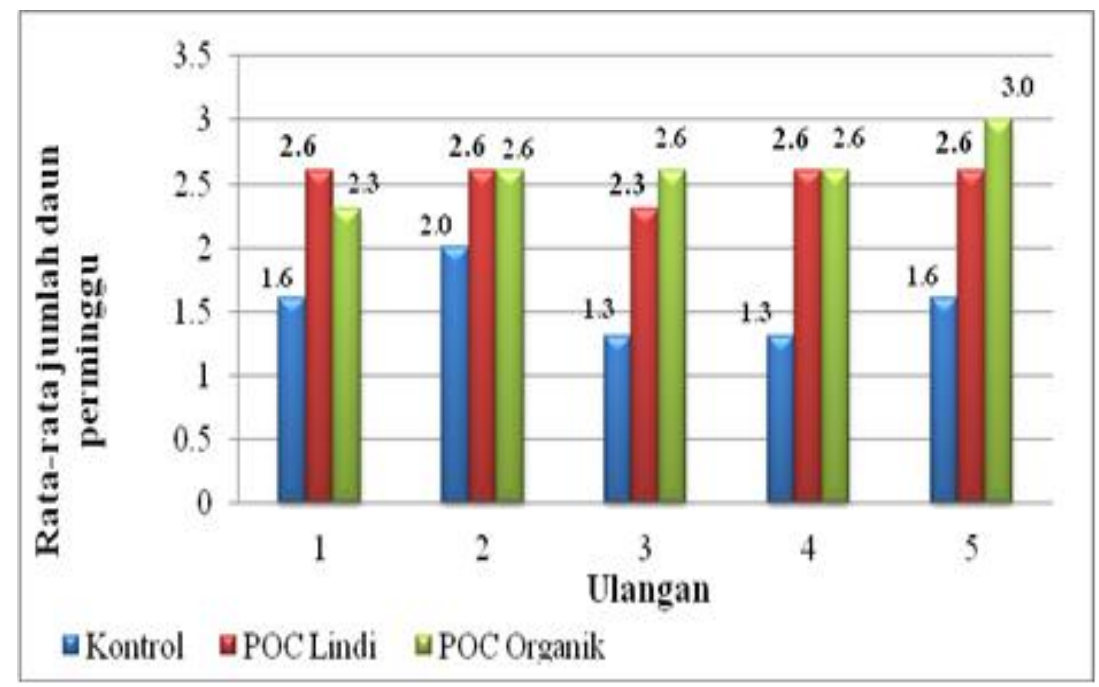

Gambar 2. Rata-rata Pertambahan Jumlah Daun Tanaman Kangkung Darat Per-minggu.

Hasil analisis sidik ragam uji efektivitas pupuk cair lindi terhadap laju pertambuhan jumlah daun pada tanaman kangkung darat ditampilkan pada Tabel 3.

Tabel 3. Analisis Ragam Pertambahan Jumlah Daun Tanaman Kangkung Darat

\begin{tabular}{|c|c|c|c|c|c|c|}
\hline \multirow{2}{*}{$\begin{array}{c}\text { Sumber } \\
\text { Keragaman } \\
\text { (SK) }\end{array}$} & \multirow{2}{*}{$\begin{array}{c}\text { Drajat } \\
\text { Bebas } \\
(\mathrm{db})\end{array}$} & \multirow{2}{*}{$\begin{array}{c}\text { Jumlah } \\
\text { Kuadrat } \\
\text { (jk) }\end{array}$} & \multirow{2}{*}{$\begin{array}{c}\text { Kuadrat } \\
\text { Tengah } \\
(\mathrm{KT})\end{array}$} & \multirow[t]{2}{*}{ F Hitung } & \multicolumn{2}{|c|}{ F. Tabel } \\
\hline & & & & & 0.05 & 0.01 \\
\hline Perlakuan & 2 & 3.484 & 1.742 & & & \\
\hline Acak & 12 & 0.652 & 0.054 & 32.061 & 3.88 & 6.93 \\
\hline Total & 14 & 4.136 & 0.296 & & & \\
\hline
\end{tabular}

Berdasarkan data pada Tabel 3. maka hasil analisis uji efektivitas pupuk organik cair lindi terhadap laju pertambahan Jumlah daun tanaman kangkung darat (Ipomoea reptans Poir) dengan nilai $\mathrm{F}_{\text {hitung }}=32,061$ sedangkan $\mathrm{F}_{\text {tabel }}=(3,88)$ pada taraf uji $5 \%$ dan $(6,92)$ pada taraf uji $1 \%$. Karena $F_{\text {hitung }}=32.061$ lebih besar dari pada $F_{\text {tabel }}$ maka $\mathrm{H}_{0}$ di tolak dan $\mathrm{H}_{1}$ diterima.

Nilai Koefisien Keragaman (KK) pertambahan jumlah daun untuk kondisi homogen tergolong kecil $(3,20 \%<5 \%)$ berarti tingkat erorr (galat) pada penelitian ini Sangat kecil, sehingga penelitian dilanjutkan dengan uji BNJ (uji beda nyata jujur), untuk menilai apakah dua rata-rata yang dibandingkan berbedanyata atau tidak (Hanafiah, 2005). Hasil uji BNJ ditampikan pada Tabel 4.

Dari hasil analisis pengujian BNJ pada Tabel 4, perlakuan kontrol berpengaruh nyata pada efektifitas pupuk organik cair terhadap laju pertambahan jumlah daun pada tanaman kangkung darat sedangkan perlakuan POC Lindi dan POC organik, tidak nyata 
pengaruhnya terhadap pertambahan jumlah daun pada tanaman kangkung darat hal ini berdasarkan pada uji BNJ 5\% dan 1\%.

Tabel 4 . Hasil Uji BNJ Pertambahan Jumlah Daun Tanaman Kangkung Darat.

\begin{tabular}{ccccc}
\hline Perlakuan & Kontrol & POC Lindi & POC Organik & \multirow{2}{*}{ Nilai BNJ } \\
\cline { 1 - 3 } y & 1.56 & 2.54 & 2.62 & \\
BNJ 5\% & $\mathrm{a}$ & $\mathrm{b}$ & $\mathrm{b}$ & 0,66 \\
BNJ 1\% & $\mathrm{a}$ & $\mathrm{b}$ & $\mathrm{b}$ & 0.92 \\
\hline
\end{tabular}

Interaksi yang terjadi antara kedua perlakuan (di luar perlakuan kontrol) pada pengamatan pertambahan jumlah daun pada tanaman kangkung darat juga menunjukan perlakuan menggunakan pupuk organik cair yang sudah ada dipasaran memberikan respon yang lebih cepat terhadap pertumbuhan jumlah daun pada tanaman kangkung namun perbedaan tidak begitu nyata karena hanya ada beberapa tanaman saja yang menunjukan pertumbuhan daunnya lebih baik dan selisih angka sangat kecil.

Pada uji BNJ tidak terdapat perbedaan yang nyata antara kedua perlakuan (di luar perlakuan kontrol) hal ini menunjukan, bahwa pupuk organik cair lindi dan pupuk cair organik memberikan hasil yang sama baiknya terhadap pertumbuhan tanaman. Sedangkan hasil uji F dan uji BNJ dapat disimpulkan bahwa pemberian pupuk organik cair berbahan dasar air lindi terbukti dapat meningkatkan laju pertambahan jumlah daun pada tanaman kangkung darat (Ipomoea reptans Poir) secara sangat nyata.

Perlakuan kontrol memberikan pengaruh yang sangat berbeda terhadap laju pertumbuhan tanaman kangkung darat sementara Faktor jenis pupuk tidak memberikan pengaruh yang berbeda terhadap pertumbuhan tanaman kangkung darat. Tidak adanya beda pengaruh antara kedua jenis pupuk dapat disebabkan karena kualitas fisik tanah yang terbentuk dari penambahan kedua jenis pupuk relatif sama. Perlakuan kotrol menunjukan pertumbuhan tanaman yang lambat hal ini dapat disebabkan karena kurangya unsur hara yang dibutuhkan oleh tanaman di dalam tanah yang digunakan pada penelitian.

Tanaman memerlukan paling sedikit 16 unsur hara agar pertumbuhanya normal. dari ke 16 unsur tersebut ada tiga unsur yakni: Karbon, hidrogen, dan oksigen yang diperoleh tanaman dari udara sedangkan 13 unsur lagi disediakan oleh tanah. Unsur tersebut adalah nitrogen $(\mathrm{N})$, fosfor $(\mathrm{P})$, kalium $(\mathrm{K})$, kalsium $(\mathrm{Ca})$, magnesium $(\mathrm{Mg})$, sulfur atau belerenf $(\mathrm{S})$, klor $(\mathrm{Cl})$, ferum atau besi $(\mathrm{Fe})$, mangan $(\mathrm{Mn})$, tembaga $(\mathrm{Cu})$, 
zink atau seng ( $\mathrm{Zn}$ ), boron (B), dan Molibdenum (Mo). Tanah dikatakan subur sempurna jika mengandung ke 13 unsur tersebut secara lengkap (Lakitan, 1993). Dari ke-13 unsur tersebut hanya enam unsur saja yang diambil tanaman dalam jumlah banyak atau disebut juga unsur makro yaitu, N,P,K,S,Ca dan Mg. namun, jika dilihat dari kegunaan keenam unsur tersebut hanya tiga unsur saja yang mutlak ada didalam tanah yang diperlukan oleh tanaman yaitu N,P dan K, sementara itu unsur lainya lagi meskipun dibutuhkan dalam jumlah banyak namun tidak terlalu berpengaruh pada pertumbuhan tanaman.

Ketersediaan unsur mikro didalam tanah juga sangat penting meskipun tanaman hanya menyerap unsur mikro dalam jumlah yang sangat sedikit, namun, jika salah satu dari unsur mikro tidak tersedia di dalam tanah maka pertumbuhan tanaman menjadi kurang optimal. Unsur mikro terdiri dari, $\mathrm{Cl}, \mathrm{Mn}, \mathrm{Fe}, \mathrm{Cu}, \mathrm{Zn}, \mathrm{B}$ dan Mo. Masingmasing unsur ini dibutuhkan dalam jumlah yang sangat sedikit sehingga diperkirakan masa habisnya di dalam tanah cukup lama. Namun, karna sistem bercocok tanam dilakukan secara terus menerus maka dampaknya tanaman akan kekurangan unsur tersebut (Lingga \& Marsono, 2013)

Air lindi umumnya mengandung senyawa organik (hidrokarbon, asam humat, fulfat, tanat dan galat) dan bahan anorganik berupa (natrium, kalsium, kalium,mangnesium, klor, sulfat, nitrogen dan beberapa senyawa logam berat). Kandungan air lindi tersebut berpotensi untuk dimanfaatkan salah satunya sebagai pupuk cair organik dengan cara mencampurkan bakteri kedalam air lindi guna membunuh bakteri patogen yang dapat merusak tanaman.

Pada kondisi tanah yang terus menerus digunakan untuk bercocok tanam dengan penggunaan pupuk anorganik atau pupuk kimia yang berlebihan dapat menyebabkan terganggunya keseimbangan unsur hara didalam tanah. Seperti halnya tanah yang digunakan dalam penelitian adalah tanah perkebunan yang digunakan secara terus menerus sehingga mengalami miskin hara, hal ini menyebabkan terganggunya pertumbuhan tanaman pada pelakuan kontrol. sementara Pada perlakuan pemberian pupuk organik cair, baik menggunakan pupuk organik cair lindi maupun pupuk organik cair yang sudah ada dipasaran menunjukan pertumbuhan tanaman yang optimal.

Karena unsur hara yang terdapat pada kedua pupuk perlakuan cukup banyak dan hampir memiliki semua unsur yang dibutuhkan tanaman baik makro ataupun mikro, 
sehingga mampu memberikan hara yang dibutuhkan tanaman baik dalam jumlah banyak ataupun sedikit dan mampu memberikan pengaruh secara optimal terhadap pertumbuhan tanaman kangkung darat (Ipomoea reptans Poir).

Dari kedua hasil percobaan dan analisis data, baik pertambahan tinggi batang maupun pertambahan jumlah daun pada tanaman kangkung darat, pada uji efektifitas pupuk organik cair lindi terhadap laju pertumbuhan tanaman kangkung darat (Ipomoea reptans Poir) menunjukan bahwa penggunaan pupuk organik cair lindi Sama baiknya dengan pupuk organik yang sudah ada di pasaran.

\section{KESIMPULAN}

Pupuk organik cair yang sudah ada dipasaran dan pupuk organik cair lindi memberikan hasil yang lebih baik terhadap tinggi batang dan jumlah daun tanaman kangkung darat dari perlakuan kontrol. Hasil uji F menunjukkan perbedaan tinggi yang nyata pada semua umur tanaman dengan pemberian kedua pupuk. Hasil uji BNJ (Uji Beda Nyata Jujur) pada efektivitas manfaat air lindi sebagai pupuk organik cair, menunjukan bahwa, pupuk organik cair lindi memberikan hasil yang sama baiknya dengan pupuk organik yang sudah ada di pasaran terhadap tinggi batang dan jumlah daun pada tanaman kangkung darat.

\section{REFERENSI}

Aditama.S. 2011. Pengaruh Pupuk Kambing Etawa terhadap pertumbuhan kangkung darat (Ipomoea reptans poir). http://faperta.ipb.ac.id/index.php/id. diunduh pada 24 Februari 2013

Arifin. A.Y. 2006. Percepatan Pematangan Kompos Dengan Bantuan air Lindi Sampah. http://faperta.ipb.ac.id/index.php/id. diunduh pada 24 Februari 2013

Daha. L, 2011. Rancangan Percobaan untuk Bidang Biologi dan pertanian. Masagena Press. Makasar.

Hanafiah. A. K. 2005. Rancangan Percobaan Aplikatif. RajaGrafindo Persada. Jakarta.

Lakitan,Benyamin. 1993. Dasar-Dasar Fisiologi Tumbuhan, Ed ke-1. Raja Grafindo Persada. Jakarta.

Lingga.P dan Marsono. 2013. Pertunjuk Penggunaan Pupuk Organik dan Anorganik. Penebar swadaya. Jakarta. 